\title{
In vitro antioxidant capacity of tea of Echinodorus grandiforus, "leather hat," in Wistar rat liver
}

\author{
RAFAELA F. LUNARDI ${ }^{1}$, MARIANE WOHLENBERG ${ }^{1}$, NIARA MEDEIROS ${ }^{1}$, FABIANE AGOSTINI ${ }^{2}$, \\ CLÁUDIA FUNCHAL ${ }^{1}$ and CAROLINE DANI ${ }^{1}$ \\ ${ }^{1}$ Centro Universitário Metodista, IPA, Centro de Pesquisas, Laboratório de Bioquímica, \\ Rua Coronel Joaquim Pedro Salgado, 80, 90420-060 Porto Alegre, RS, Brasil \\ ${ }^{2}$ Universidade de Caxias do Sul, UCS, Laboratório de Óleos Essenciais, Rua Francisco Getúlio Vargas, \\ 1130, 95070-560 Caxias do Sul, RS, Brasil
}

Manuscript received on December 9, 2013; accepted for publication on May 3, 2014

\begin{abstract}
Oxidative stress has been considered as one of the factors responsible for hepatic diseases, which sometimes require new ways of treatment. The present study aimed to evaluate the in vitro antioxidant capacity of the tea of Echinodorus grandiforus ("leather hat" plant) in rat liver. Different preparations of tea were evaluated for phenolic composition, antioxidant activity by DPPH assay and ability to inhibit lipid peroxidation induced by copper sulfate. The antioxidant activity was assessed in liver tissue treated with sodium azide in the presence or absence of tea by assays for lipid peroxidation (TBARS), protein oxidation (carbonyl) and the antioxidant enzymes catalase (CAT) and superoxide dismutase (SOD). The results show that different preparations of tea are important sources of polyphenols and contain theobromine, catechin and vitexin. Furthermore, the results indicate that this tea exhibits an antioxidant activity by its ability to scavenge DPPH radical. Different preparations of tea prevented damage to lipids and proteins induced by sodium azide, as well as assisting in restoring CAT and SOD activities. Thus, it can be seen that E. grandiforus tea had antioxidant activity in serum and liver being able to prevent oxidative damages generated by sodium azide.
\end{abstract}

Key words: oxidative stress, phenolic compounds, reactive species, sodium azide.

\section{INTRODUCTION}

The liver is a vital organ that performs important functions in the body, such as the synthesis of proteins and enzymes, detoxification, hormonal balance, and storage of vitamins and minerals, among other things (Navarro and Senior 2006, Cemek et al. 2012). Several in vitro and in vivo studies suggest that oxidative stress may be related to liver damage. Thus, it contributes to lipid

Correspondence to: Caroline Dani

E-mail: caroline.dani@metodistadosul.edu.br peroxidation, one of the critical factors involved in the genesis and progression of nonalcoholic steatohepatitis and liver cancer (Weltman et al. 1998, Ha et al. 2010).

Oxidative stress results from an imbalance between the capacity of antioxidants and the amount of reactive species, which when produced in excess can cause various diseases, such as ischemia, inflammation, degenerative diseases, hepatitis, etc. Antioxidants are able to reduce the damage to cells caused by reactive species. They can be divided 
into enzymatic antioxidants (endogenous), including superoxide dismutase (SOD) and catalase (CAT), and non-enzymatic antioxidants (exogenous), especially compounds of dietary origin, such as flavonoids (Pietta 2000, Koury and Donangelo 2003).

Among the plants rich in flavonoids, the species Echinodorus grandiflorus, of the family Alismataceae, stands out. E. grandiflorus is a semi-aquatic plant native to Brazil and found throughout the country, mainly in tropical regions. It is popularly known as "leather hat" and is widely used in folk medicine, in the treatment of various diseases (Souza et al. 2004, Tibiriçá et al. 2007, Brugiolo et al. 2010). According to Pimenta et al. (2006), its leaves are popularly used as a diuretic and anti-inflammatory remedy, as well as for treating kidney and liver disorders. The active ingredients identified in the plant include the flavonoids. These compounds have an ideal structure for scavenging reactive species and are considered effective antioxidants (Costa et al. 1999, Halliwell 2007, Garcia et al. 2010).

However, up until now there are no published data demonstrating the antioxidant activity of $E$. grandiflorus. Therefore, the present study evaluated the in vitro antioxidant activity of E. grandiflorus tea against oxidative stress induced by sodium azide in Wistar rat liver.

\section{MATERIALS AND METHODS}

CHEMICALS

Thiobarbituric acid was purchased from Merck (Darmstadt, Germany) and DPPH (2,2-diphenyl-1picrylpicryhydrazyl) from Sigma (St. Louis, MO, USA). All other reagents were purchased from local suppliers, and the analyses were performed at the Centro Universitário Metodista, at IPA, Porto Alegre, RS, Brazil.

PREPARATION OF TEA

Leaves of E. grandiflorus were provided by the Company Santosflora Trade Herbal Ltda (scientific name: Echinodorus grandiflorus; lot CHPC01/0512; São Paulo, Brazil). The leaves were properly dried (sun-drying method).

To evaluate the total and isolated polyphenols, the tea was prepared using the method adapted from Tibiriçá et al. (2007). First, four concentrations of tea were prepared $(5,10,15$, and $20 \mathrm{~g} / 100 \mathrm{~mL})$, based on previous studies (Pinto et al. 2007, Garcia et al. 2010).

Subsequently, two concentrations, 0.4 and 0.8 $\mathrm{g} / 100 \mathrm{ml}$, were used for biological evaluations. The tea was prepared following the supplier's recommendations, using dried leaves infused in boiling drinking water. After preparation, the samples were allowed to cool at room temperature, followed by filtration and then stored in a freezer until the time of analysis.

PHENOLICS

The total phenolic content was measured according to Singleton et al. (1999) using the modified FolinCiocalteu colorimetric method. The results were expressed as mg gallic acid/mL.

Phenolic compounds were identified by HPLC, where chlorogenic acid, taxifolin, ferulic acid, naringin, rutin, quercetin, luteolin, kaempferol, apigenin and vitexin were determined. For tannins, catechin and epicatechin were determined, while for alkaloids, caffeine, theophylline and theobromine. All patterns were evaluated using an HPLC HP 1100 with Lichrospher RP-18 (5 $\mu \mathrm{m})$ column, equipped with a UV detector and a quaternary pump system, with a flow rate of $1.0 \mathrm{~mL} / \mathrm{min}$ and an injection volume of $50 \mu \mathrm{L}$, and the results were expressed in $\mu \mathrm{g} / \mathrm{ml}$. The quantification of catechin was performed as described by Saucier et al. (2001), where solvent A consisted of water with $5 \%$ acetic acid, and solvent B consisted of methanol with 5\% acetic acid. Separation was by isocratic elution with $90 \% \mathrm{~A}$ and $10 \%$ solvent B; total analysis time was $45 \mathrm{~min}$, and detection at $280 \mathrm{~nm}$. For quantification of rutin, quercetin, kaempferol and naringin, solvent 
A consisted of methanol with $2 \%$ acetic acid and solvent B Milli-Q water with $2 \%$ acetic acid; total analysis time was $60 \mathrm{~min}$, and detection at 350 $\mathrm{nm}$. The HPLC system for alkaloids consisted of an RP18 reversed-phase column, gradient elution, detection at $280 \mathrm{~nm}$, flow rate of $1 \mathrm{~mL} / \mathrm{min}$, analysis time of $45 \mathrm{~min}$ and column temperature of $25^{\circ} \mathrm{C}$ (Fillip et al. 2001).

Ability of the TeA to ScAVEnge the Free RadicAL 2,2-DIPHENYL 1-PICRYLHYDRAZYL (DPPH •)

The antioxidant capacity of tea was assessed using the modified technique of Yamaguchi et al. (1999). This technique is routinely used as a preliminary test to estimate the antioxidant activity of natural compounds, and the results are expressed as percentage $(\%)$ of scavenged DPPH free radical.

LIPID PEROXIDATION INDEX (TBARS) IN SERUM

Inhibition of lipid peroxidation in serum was determined by the modified method of Durak et al. (1999). Venous blood $(10 \mathrm{~mL})$ was drawn from 4 healthy young adults. After the collections, the blood was centrifuged at $3500 \mathrm{rpm}$ for 10 minutes and serum was separated. Subsequently, the sera were mixed. The fresh pooled human serum was incubated at $37^{\circ} \mathrm{C}$ for 1 hour, and levels of oxidative stress were measured spectrophotometrically (Bioespectro model SP-2200), according to the groups listed below, and expressed as concentration of thiobarbituric acid-reactive substances (TBARS) as described by Willis (1996). Six groups were prepared in duplicate, four control groups (serum, serum and $50 \mathrm{mM}$ copper sulfate $\mathrm{CuSO}_{4}$, serum and $0.4 \%$ leather hat tea, and serum and $0.8 \%$ leather hat tea) and two analysis groups (serum plus $0.4 \%$ leather hat tea and $\mathrm{CuSO}_{4}$ and serum plus $0.8 \%$ leather hat tea and $\mathrm{CuSO}_{4}$ ). These were incubated for thirty minutes at $37^{\circ} \mathrm{C}$ without $\mathrm{CuSO}_{4}$, and thereafter, this was added in the control (serum and $\mathrm{CuSO}_{4}$ ) and analysis groups. All groups were again incubated for one hour at $37^{\circ} \mathrm{C}$. Results of TBARS were expressed as nmol/mL.
ANTIOXIDANT ACTIVITY in vitro

\section{Animals}

The number of animals was defined based on previous studies, where five ten-day-old Wistar rats (Spada et al. 2009) from the Centro Universitário Metodista, IPA, Porto Alegre, RS, Brazil were used, with the approval of the Ethics Committee of Animal Use, under protocol number 02/2012. The animals were maintained under standard laboratory conditions and kept in 12-hour light-dark cycle at a constant temperature $\left(22^{\circ} \mathrm{C} \pm 1^{\circ} \mathrm{C}\right)$, with free access to food and water. The animals were sacrificed by decapitation without anesthesia and the liver was removed and stored at $-4^{\circ} \mathrm{C}$ until analysis.

\section{Tissue Preparation}

The liver was homogenized in $1.5 \% \mathrm{KCl}$ and it was divided into four control groups (tissue, tissue plus $5 \mathrm{mM}$ sodium azide; tissue plus $0.4 \% \mathrm{E}$. grandiflorus tea, tissue plus $0.8 \%$ E. grandiflorus tea) and two analysis groups (tissue plus $0.4 \%$ E. grandiflorus tea and sodium azide; tissue plus $0.8 \%$ E. grandiflorus tea and sodium azide). These were incubated for thirty minutes at $37^{\circ} \mathrm{C}$ without sodium azide. Subsequently, this was added in the control group (tissue plus sodium azide) and to the analysis groups, where all groups were again incubated for one hour at $37^{\circ} \mathrm{C}$. After incubation, we evaluated the activities of the antioxidant enzymes superoxide dismutase and catalase and the rates of lipid peroxidation (TBARS) and protein oxidation (carbonyl).

\section{Index of lipid peroxidation (TBARS)}

The index of lipid peroxidation in liver was determined by Wills (1996). Thiobarbituric acidreactive substances (TBARS) are used as a measure of lipid peroxidation, with absorbance being read at $535 \mathrm{~mm}$ (Bioespectro spectrophotometer, model SP2200). Results were expressed as nmol/mg protein. 


\section{Index of protein oxidation (carbonyl)}

The determination of carbonyl groups was performed in accordance to Levine et al. (1990). This technique determines the oxidative damage to proteins, on the basis of the reaction with dinitrophenylhydrazine (DNPH) and reading at 370 $\mathrm{nm}$ (Bioespectro spectrophotometer, model SP2200). Results were expressed as nmol/mg protein.

\section{Superoxide dismutase}

Superoxide dismutase (SOD) enzyme activity was determined in accordance to Bannister and Calabrese (1987). It is a technique based on the decrease in superoxide anion radical measured at $480 \mathrm{~nm}$ (Bioespectro spectrophotometer, model SP-2200), with enzyme activity expressed as USOD/mg protein.

\section{Catalase}

Catalase (CAT) activity was determined by the decay of hydrogen peroxide $\left(\mathrm{H}_{2} \mathrm{O}_{2}\right)$ measured at 240 nm (Hitachi U-3000 UV-Vis spectrophotometer), in accordance to Aebi (1984). The result was expressed as UCAT/mg protein.

PROTEIN CONTENT

Protein content was determined in accordance to the method of Lowry et al. (1951) using bovine serum albumin as standard.

STATISTICAL ANALYSIS

The normal distribution of data was verified by the Kolmogorov-Smirnov test. Student's t-test was used to evaluate the antioxidant activity of the tea. Other data were analyzed by analysis of variance (ANOVA), and the means were compared by the Tukey post-test. The Statistical Package for the Social Sciences (SPSS) version 17.0 was used for all statistical analyses. Differences were considered significant at $\mathrm{p}<0.05$.

\section{RESULTS AND DISCUSSION}

The E. grandiflorus tea is traditionally used in folk medicine for combating various diseases. This therapeutic action is attributed to the presence of phenolic compounds, which are related to the prevention of many diseases. These are important secondary metabolites synthesized by plants during normal development and also in response to stress conditions. Many of these compounds provide antioxidant action, capable of protecting cells against oxidative damage (Shahidi and Naczk 1995, Bhandari and Kawabata 2004).

In our study, we found that the E. grandiflorus tea is rich in phenolic compounds (Figure 1). This finding concurs with the study of Flor et al. (2010), who showed a substantial presence of polyphenols in an extract of E. grandiflorus, which included flavonoids and their secondary metabolites (flavones, flavonols and flavanones). Garcia et al. (2010) identified the presence of flavonoids, diterpenes and isovitexin in extracts of E. grandiflorus. These compounds were also observed in green, black (Camellia sinensis (L.) $O$. Kuntze) and mate (Ilex paraguariensis A. St.-Hil) tea (Barg et al. 2014). When evaluating different tea preparations, we found that the total polyphenol content increased as per the concentration, with the $20 \%$ concentration being richest in phenolic compounds (Figure 1A). The levels of catechin were higher in 15 and 20\% tea and did not differ between tea preparations (Figure 1D1). However, the amounts of chlorogenic acid (Figure 1B1), ferulic acid (Figure 1B2), vitexin (Figure 1C), epicatechin (Figure 1D2), caffeine (Figure 1E3) and theophylline (Figure 1E2) were highest in 15\% tea, and decreased in $20 \%$ tea.

Among the isolated compounds in tea, we focused on the compounds that were the most abundant, were vitexin, theobromine (Figure 1E1) and catechin. Theobromine showed the highest concentration, as also seen in black tea (Camellia 
sinensis (L.) O. Kuntze) (Van Breda et al. 2013). Kuntze), while vitexin has been found in leaves Catechin and epicatechin have been detected in of yellow passion fruit (Passiflora edulis Sims $f$. green and black tea (Camellia sinensis (L.) O. Alavicarpa Deneger) (Peres et al. 2011).
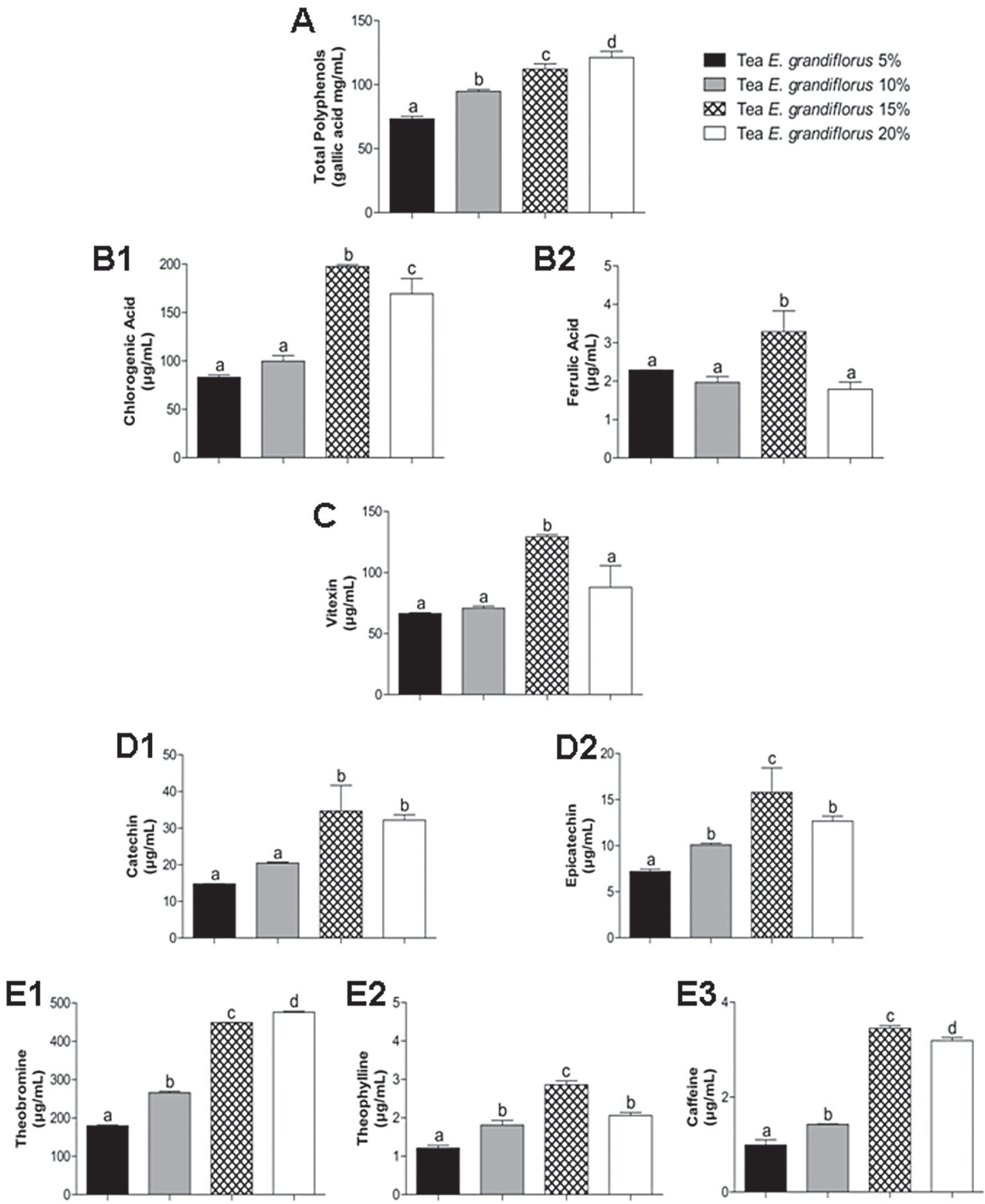

Figure 1 - Content of phenolic compounds in different preparations of tea of Echinodorus grandiflorus (leather hat). A: Total Polyphenols; B: Class of Phenolic Acids (B1: Chlorogenic Acid; B2: Ferulic Acid); C: Class of Flavonoids (Vitexin) D: Class of Catechins (D1: Catechin; D2: Epicatechin); E: Class of Xanthines (E1: Theobromine; E2: Theophylline; E3: Caffeine). p $<0.05$, according to ANOVA, followed by Tukey post-test. Different letters (a, b, c, d) indicate a statistical difference between groups. 
In evaluating in vitro antioxidant activity, both preparations of tea, $0.4 \%(22.4 \pm 1.7 \%)$ and $0.8 \%$ $(41.3 \pm 1.1 \%)$ were able to scavenge DPPH, with the higher concentration showing significantly higher scavenging capacity $(\mathrm{p}<0.05)$. The same was found for the plant Limnocharis flava (L.) Buchenau, also belonging to the family Alismataceae, which contained polyphenols and ascorbic acid and showed the ability to scavenge DPPH (Sakong et al. 2011). In another study, the antioxidant activity of green tea (Camellia sinensis (L.) O. Kuntze) was demonstrated using the DPPH assay, and it also showed the presence of polyphenols and catechins (Barg et al.2014). These results suggest a relationship between the presence of these compounds and the antioxidant activity demonstrated.

The use of plants for medicinal purposes is one of the oldest forms of medical practice to treat, cure and prevent diseases (Veiga et al. 2005). The plant E. grandiflorus, "leather hat," is traditionally used to fight a variety of illnesses (Rieder et al. 2011).
In our study, we found that E. grandiflorus tea had beneficial effects against oxidative damage induced in rat liver, while other studies have also shown some benefits of using the plant E. grandiflorus.

According to Portella et al. 2012, the leaves of Echinodorus macrophyllus exert a nephroprotective effect in Wistar rats (Portella et al. 2012). Brugiolo et al. (2011) showed that the extract of $E$. grandiflorus was able to modulate allergic pulmonary inflammation, and it may also be useful as a potential therapeutic agent for asthma (Lessa et al. 2008).

When evaluating the ability of tea to prevent the induction of lipid peroxidation in human serum (Figure 2), it was observed that the peroxidation inducer, $\mathrm{CuSO}_{4}$, raised the levels of TBARS, and that both preparations of tea tested were ineffective in reducing these levels. This is in line with the findings of Nasser et al. 2011, who observed no statistical difference in lipid peroxidation in human serum, before and after the addition of orange juice (Nasser et al. 2011). However, another study

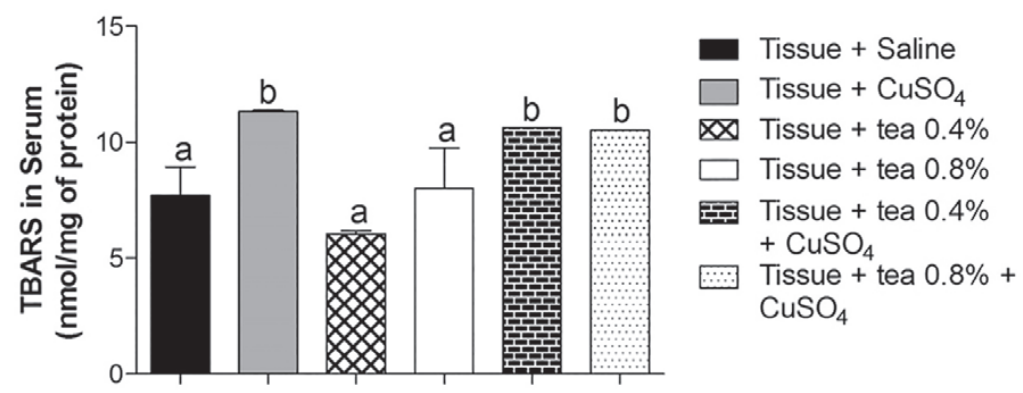

Figure 2 - Effect of tea of Echinodorus grandiflorus (leather hat) on thiobarbituric acid-reactive substances (TBARS) in human serum. Data are expressed as mean \pm standard deviation and were statistically analyzed by analysis of variance (ANOVA) followed by Tukey post-test. Different letters indicate significant differences between groups, with $\mathrm{p}<0.05$.

showed that grape juice protected against $\mathrm{CuSO}_{4}{ }^{-}$ induced lipid peroxidation in serum, except for conventional white grape juice (Dani et al. 2007). In this study the authors attributed the ability to inhibit lipid peroxidation to the content of polyphenols and ascorbic acid, since the grape juice that showed no ability to prevent the damage contained lower amounts of these compounds. These results suggest that these antioxidant compounds, when present in greater amounts, provide protection against lipid peroxidation.

In vitro antioxidant activity in rat liver was evaluated using the lipid peroxidation (TBARS) (Figure 3A) and protein oxidation (carbonyl) 
(Figure 3B) assays. It was observed that sodium azide caused oxidative damage to the tissue due to its capacity to inhibit the electron transport chain at complex IV (Champe et al. 2011).
Based on TBARS and carbonyl assays, it was observed that sodium azide damage tissue lipids and proteins. Both preparations of tea tested were able to inhibit lipid peroxidation and protein
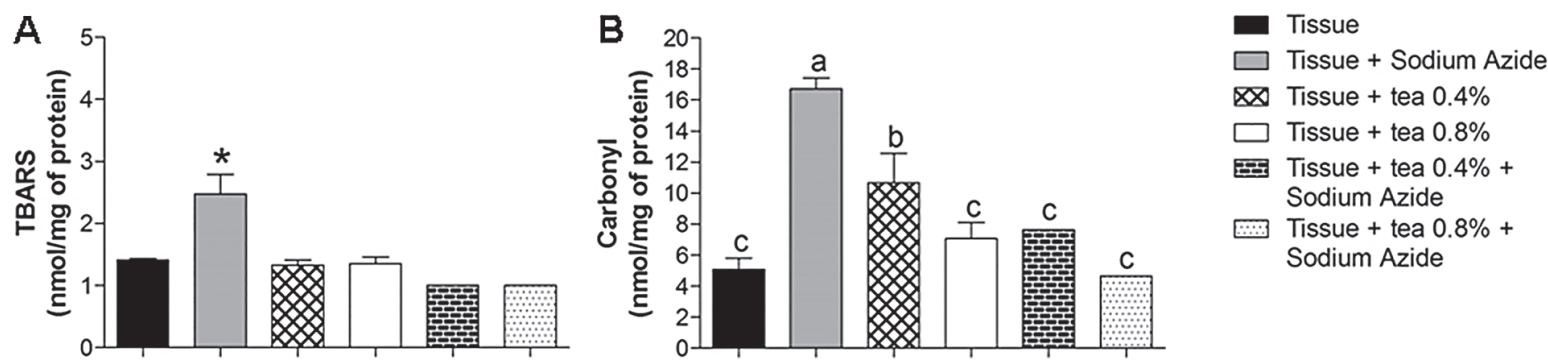

Figure 3 - Effect of tea of Echinodorus grandiflorus (leather hat) on thiobarbituric acid-reactive substances (TBARS) (Fig. 3A) and protein carbonyl (Fig. 3B) levels in rat liver. Data are expressed as mean \pm standard deviation and were statistically analyzed by analysis of variance (ANOVA) followed by Tukey post-test. Different letters indicate significant differences between the groups. ${ }^{*} \mathrm{p}<0.05$, statistically different from the other groups.

damage, demonstrating protection against sodium azide-induced damage $(\mathrm{p}<0.05)$. Dani et al. (2008) and Schmitz et al. (2009), working with rat liver, found that green tea extract was also able to reduce TBARS and that grape juice was effective in reducing carbonyl levels, respectively. Some studies have revealed the presence of phenolic compounds and more specifically those of catechin compounds (Dani et al. 2008, Barg et al. 2014). A similar trend was reported by Hong et al. (2006) who evaluated the treatment of rat liver with an extract of Alisma orientalis (family Alismataceae). It was found that the plant was useful in the prevention of oxidative stress by decreasing lipid peroxidation, as seen with other plants of the same family.

To check the activity of antioxidant enzymes, superoxide dismutase (SOD) and catalase (CAT) activities were evaluated in rat liver (Figure 4). These enzymes are included in the enzymatic defense system. SOD converts superoxide ion $\left(\mathrm{O}_{2}^{-}\right)$to hydrogen peroxide $\left(\mathrm{H}_{2} \mathrm{O}_{2}\right)$, while CAT converts $\mathrm{H}_{2} \mathrm{O}_{2}$ to water and oxygen by preventing the formation of hydroxyl radical $\left(\mathrm{OH}^{-}\right)$which is highly toxic (Ho et al. 2001, Halliwell 2006). In our study, we found that sodium azide induced an increase in CAT (Figure 4A) and
SOD (Figure 4B) activity in the tissue. Meanwhile, both concentrations of tea tested were able to restore activity close to those of the control levels, since the tea helped in attenuate the induced damage. This corroborated the earlier findings by Hong et al. (2006) and Dani et al. (2008), who determined the effects of Alisma orientalis extract and grape juice on rat liver, respectively. These studies demonstrated similar effects on SOD and CAT activity and also observed that the juice and extract were able to reverse the tissue damage induced.

As we know, antioxidants can neutralize oxidative stress in different ways, such as inhibiting free radical formation (preventive antioxidants), interrupting autoxidation chain reactions (chain breaking antioxidants), up-regulating and protecting cellular antioxidant defense mechanisms (indirect antioxidants), neutralizing the action of metal prooxidant ions (metal chelators), inhibiting the action of prooxidative enzymes (enzyme inhibitors) and increasing the activities of other antioxidants (Khlebnikov et al. 2007, Carocho and Ferreira 2013, Georgiev et al. 2014). As also mentioned, polyphenols are involved in the defense against oxidative damage, which could explain why these food components contributed to preventing oxidative 

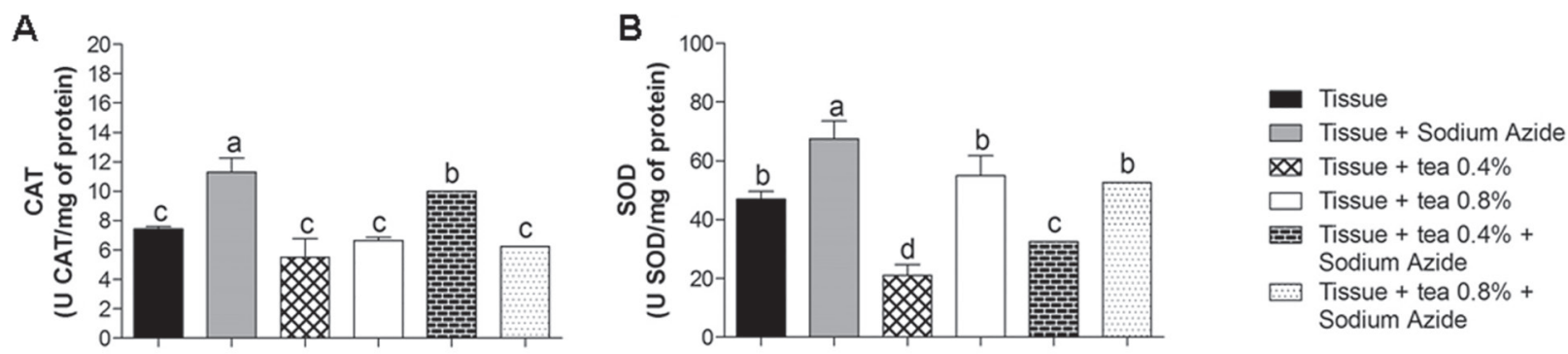

Figure 4 - Effect of tea of Echinodorus grandiflorus (leather hat) on the activity of antioxidant enzymes catalase (CAT) (Fig. 4A) and superoxide dismutase (SOD) (Fig. 4B) in rat liver. Data are expressed as mean \pm standard deviation and were statistically analyzed by analysis of variance (ANOVA) followed by Tukey post-test, $\mathrm{p}<0.05$.

damage and lipid peroxidation by E. grandiflorus tea as well. Some studies have confirmed the potent activity of polyphenolic compounds countering lipid peroxidation and scavenging various radicals, including $\mathrm{H}_{2} \mathrm{O}_{2}$. It has been suggested that plant phenols have multifunctional biochemical activities including: (i) electrophilic radical trapping, (ii) inhibition of nitrosation, (iii) arachidonic metabolism modulation and (iv) alteration of carcinogen metabolism (Tseng et al. 1996, Sroka and Cirowski 2003).

The antioxidant activity of polyphenols depends on the bioavailability of these compounds. Several studies have suggested that some flavonoids present in the diet can have positive effects on the human body, regardless of their poor absorption. The flavonoids found in blood and specific organs that result from digestive or liver activity may differ from native substances in terms of biological activity (Manach et al. 2004, Georgiev et al. 2014). The bioavailability of flavonoids is dependent on their structural properties, and they are poorly absorbed because they occur naturally in highly hydrophilic glycosylated forms. Thus, only aglycones can effectively pass through the gut wall. It has been suggested that some species of colon microflora can hydrolyze flavonoid glycosides to their corresponding aglycones, although the microbial enzymes may also degrade the entire compound as well (Bentz 2009, Georgiev et al. 2014).

In general, teas are extensively studied and they have scientifically proven benefits. However, studies suggest that phenolic compounds present in various teas can also act as prooxidants in the presence of redox-active chemicals and lead to the formation of reactive oxygen species, which can cause damage to DNA, lipids and other biological molecules (Decker 1997, Jain et al. 2013). The balance between prooxidant and antioxidant effects of flavonoids is crucial to evaluate the toxicity of teas. With regards to this toxicity, there have been reports of some severe allergic reactions (Jain et al. 2013) and nervous irritability, convulsions, tachycardia, extrasystoles, and gastric irritation (due to the presence of xanthine) (Brem et al. 1977, Jain et al. 2013). However, to date, we do not know enough about the toxic effects of E. grandiflorus tea.

\section{CONCLUSION}

On the basis of the findings of this study, it can be concluded that E. grandiflorus tea had antioxidant activity in the liver, where it was able to reverse the damage caused by lipid peroxidation and protein oxidation, besides normalizing the activity of the antioxidant enzymes SOD and CAT. Furthermore, it is suggested that this tea can help prevent liver damage caused by free radicals. This is important because many synthetic drugs used in treatment are often insufficient and may have serious adverse effects (Arhoghro et al. 2009). However, further studies are needed to provide more knowledge about the composition and therapeutic actions of E. grandiflorus tea. 


\section{ACKNOWLEDGMENTS}

We are grateful to Centro Universitário Metodista, IPA (Porto Alegre, RS, Brazil), Fundação de Amparo à Pesquisa do Estado do Rio Grande do Sul (FAPERGS), Conselho Nacional de Desenvolvimento Científico e Tecnológico (CNPq) and Coordenação de Aperfeiçoamento de Pessoal de Nível Superior (CAPES) for their help and financial support during this research.

\section{RESUMO}

O estresse oxidativo tem sido referido como um dos fatores responsáveis pelo desencadeamento de hepatopatias, sendo necessárias novas formas de tratamento. O presente estudo teve como objetivo avaliar a capacidade antioxidante in vitro do chá de Echinodorus grandiforus "Chapéu de couro" em fígado de ratos. Nas diferentes preparações de chá foram avaliadas a composição fenólica, a atividade antioxidante pelo ensaio do DPPH e a capacidade de inibição de peroxidação lipídica induzida por sulfato de cobre. A atividade antioxidante foi avaliada em tecidos hepáticos tratados com azida sódica na presença ou ausência de chá, por meio do ensaio de peroxidação lipídica (TBARS), oxidação proteica (Carbonil) e atividade das enzimas antioxidantes catalase (CAT) e superóxido dismutase (SOD). Os resultados demonstram que as diferentes concentrações de chá são fontes importantes de polifenóis, destacando o conteúdo de teobromina, catequina e vitexina. Além disto, os resultados indicam que o chá apresenta atividade antioxidante pela sua capacidade em varrer o radical DPPH. As diferentes preparações de chá foram capazes de impedir os danos a lipídios e proteínas induzidos pela azida sódica, bem como auxiliar no restabelecimento da atividade de enzimas CAT e SOD. Deste modo, pode-se verificar que o chá E. grandiflorus apresentou atividade antioxidante no soro e no fígado, sendo capaz de prevenir danos oxidativos gerados pela azida sódica.

Palavras-chave: estresse oxidativo, compostos fenólicos, espécies reativas, azida sódica.

\section{REFERENCES}

AEBI H. 1984. Catalase in vitro. Methods Enzymol 105: 121-126.

ArHoghro E, EKPo K, ANOSIKE E AND IBEH G. 2009. Effect of aqueous extract of bitter leaf (Vernonia Amygdalina Del) on carbon tetrachloride $\left(\mathrm{CCl}_{4}\right)$ induced liver damage in albino Wistar rats. Eur J Sci Res 26: 122-130.

BANNISTER J AND CAlABRESE L. 1987. Assays for SOD. Methods Biochem. Anal 353: 279-312.

BARG M ET AL. 2014. Evaluation of the protective of Ilex paraguariensis and Camellia sinensis extracts on the prevention of oxidative damage caused by ultraviolet radiation. Environ Toxicol Pharmacol 37: 195-201.

BENTZ AB. 2009. A review of quercetin: Chemistry, antioxidant properties, and bioavailability. J Young Investig Available online: http://www.jyi.org/research/re.php?id=3416 (accessed on 16 March 2014).

BHANDARI M AND KAWABATA J. 2004. Organic acid, phenolic content and antioxidant activity of wild yam (Dioscorea spp.) tubers of Nepal. Food Chem 88: 163-168.

Brem SS, Gullino PM AND Medina D. 1977. Angiogenesis: A marker for neoplastic transformation of mammary papillary hyperplasia. Science 195: 880-882.

BRUGiolo A ET AL. 2011. Effects of aqueous extract of Echinodorus grandiflorus on the immune response in ovalbumin-induced pulmonary allergy. Ann Allergy Asthma Immunol 106: 481-488.

Brugiolo S, Peters V, Pimenta D, Aarestrup B, Brugiolo A, RIBEIRO D AND GUERRA M. 2010. Reproductive toxicity of Echinodorus grandiflorus in pregnant rats. J Toxicol Sci 35: 911-922.

CAROCHO M AND FERREIRA ICFR. 2013. A review on antioxidants, prooxidants and related controversy: Natural and synthetic compounds, screening and analysis methodologies and future perspectives. Food Chem Toxicol 51: 15-25.

Cemek M, Yilmaz F, BÜyÜKokuroglu M, BÜYÜKben A, AYMELEK F AND AYAZ A. 2012. Serum and Liver Tissue Bio-Element Levels, and Antioxidant Enzyme Activities in Carbon Tetrachloride-Induced Hepatotoxicity: Protective Effects of Royal Jelly. J Med Food 1: 1-7.

ChAMPe P, HARVEY R AND FERRIER D. 2011. Biochemistry, $5^{\text {th }}$ ed., Philadelphia: Lippincott Williams \& Wilkins, 520 p.

Costa M, Tanaka C, Imamura P and Marsaioli A. 1999. Isolation and synthesis of a new clerodane from Echinodorus grandiflorus. Phytochemistry 50: 117-122.

Dani C, Oliboni L, Pasquali M, Oliveira M, Umezu F, SALVADOR M, MOREIRA J AND HENRIQUES J. 2008. Intake of Purple Grape Juice as a Hepatoprotective Agent in Wistar Rats. J Med Food 11: 127-132.

DANiC, OLIBONI L, VANDERLINDE R, BONATTOD, SALVADOR M AND HENRIQUES J. 2007. Phenolic content and antioxidant activities of white and purple juices manufactured with organically- or conventionally-produced grapes. Food Chem Toxicol 45: 2574-2580. 
DECKER EA. 1997. Phenolics: prooxidants or antioxidants? Nutr Rev 55: 396-407.

DuraK I, AVCi A, KaÇMAZ M, BÜYÜKKOÇAK S, CIMEN M, ElgÜN S AND OzTÜRK H. 1999. Comparison of antioxidant potentials of red wine, white wine, grape juice and alcohol. Curr Med Res Opin 15: 316-320.

Fillip R, López P, Gilberti J, Coussio J and Ferraro G. 2001. Phenolic compounds in seven South American Ilex species. Fitoterapia 72: 774-778.

FLOR R, CAMPOS M, SOLANO A, JOKL L AND DANTAS-BARROS A. 2010. Drying of Echinodorus macrophyllus and autoclaving and lyophilization of the fluid-extract: effects on the pharmacochemical composition. J Pharmacog 21: 518-524.

Garcia E, Oliveira M, Godin A, Ferreira W, Bastos L, COELHO M AND BRAGA F. 2010. Antiedematogenic activity and phytochemical composition of preparations from Echinodorus grandiflorus leaves. Phytomedicine 18: 80-86.

Georgiev V, Ananga A And Tsolova V. 2014. Recent Advances and Uses of Grapes Flavonoids and Nutraceuticals. Nutrients 6: 391-415.

Ha H, ShIn H, Feitelson M AND Yu D. 2010. Oxidative stress and antioxidants in hepatic pathogenesis. World $\mathrm{J}$ Gastroenterol 16: 6035-6043.

Halliwell B. 2006. Reactive Species and Antioxidants. Redox Biology Is a Fundamental Theme of Aerobic Life Plant Physiol 141: 312-322.

Halliwell B. 2007. Dietary polyphenols: Good, bad, or indifferent for your health? Cardiovasc Res 73: 341-347.

Ho J, Zheng S, Comhair S, Farver C and ERZurum S. 2001. Differential Expression of Manganese Superoxide Dismutase and Catalase in Lung Cancer. Cancer Res 61: 8578-8585.

Hong X, TAng H, Wu L And Li L. 2006. Protective effects of the Alisma orientalis extract on the experimental nonalcoholic fatty liver disease. J Pharm Pharmacol 58: 1391-1398.

JAIN A, MANGHANI C, NIGAM DAND RANI V. 2013. Tea and human health: The DARK SHADOWS. Toxicol Lett 220: 82-87.

KHLEBNIKOV AI, SCHEPETKIN IA, DOMINA NG, KIRPOTINA LN AND QUINN MT. 2007. Improved quantitative structureactivity relationship models to predict antioxidant activity of flavonoids in chemical, enzymatic, and cellular systems. Bioorg Med Chem 15: 1749-1770.

KOURY J AND DONANGELO C. 2003. Zinc, oxidative stress and physical activity. Rev Nutr 16: 433-441.

Lessa M, Araújo C, Kaplan M, Pimenta D, Figueiredo M AND TIBIRIÇÁ E. 2008. Antihypertensive effects of crude extracts from leaves of Echinodorus GRANDIFLORUS. Fundam Clin Pharmacol 22: 161-168.

LEVINE R, GARlAND D, OLIVER C, AMICI A, Climent I, LENZ A, AHN B, SHALTIEL S AND STADTMAN E. 1990. Determination of carbonyl content in oxidatively modified proteins. Methods Enzymol 18: 464-478.

Lowry O, Rosebrough N, FARR A AND RANDALl R. 1951. Protein measurement with the folin phenol reagent. J Biol Chem 193: 265-267.
MANACH C, SCALBERT A, MORAND C, RÉMÉSY C AND JiMÉNEZ L. 2004. Polyphenols: Food sources and bioavailability. Am J Clin Nutr 79: 727-747.

Nasser A, Dourado G, Manjate D, Carlos I and Cesar T. 2011. Evaluation of oxidative stress in the blood of habitual consumers of orange juice. Rev Ciênc Farm Básica Apl 32: 275-279.

NAVARRO V AND SENIOR J. 2006. Drug related hepatotoxicity. N Engl J Med 354: 731-739.

Peres RG, TONIn FG, TAVARES MF AND RodrigueZ-AmayA DB. 2011. Determination of catechins in green tea infusions by reduced flow micellar electrokinetic chromatography. Food Chem 127: 651-655.

PIETTA P. 2000. Flavonoids as antioxidants. J Nat Prod 63: 1035-1042.

Pimenta DS, Figueiredo MR and Kaplan MAC. 2006. Essential oil from two populations of Echinodorus grandiflorus (Cham. \& Schltd1.) Micheli (Chapéu de couro). An Acad Bras Cienc 78: 623-628.

Pinto A, Rego G, Siqueira A, Cardoso C, Reis P, Marques E, CoElho M AND SABINO K. 2007. Immunosuppressive effects of Echinodorus macrophyllus aqueous extract. J Ethnopharmacol 111: 435-439.

Portella V, Cosenza G, Diniz L, Pacheco L, Cassali G, CALIARI M, BRANDÃo M AND VIEIRA M. 2012. Nephroprotective Effect of Echinodorus macrophyllus Micheli on Gentamicin-Induced Nephrotoxicity in Rats. Nephron Extra 2: 177-183.

Rieder A, Figueiredo GC AND Bonilla MG. 2011. Plant known as "Leather hat" (Echinodorus spp. (Alimastaceae) and its medicinal use in southwestern Mato Grosso, Brazil. Planta Med 77(12): PF 86; 1327.

SAKONG P, KHAMPITAK T, CHA'ON U, PINITSOONTORN C, SRiboonlue P, YongVanit P AND Boonsiri P. 2011 Antioxidant activity and bioactive phytochemical contents of traditional medicinal plants in northeast Thailand. $\mathrm{J}$ Med Plants Res 5: 6822-6831.

Saucier C, Mirabel M, Daviud F, Longieras A AND GLORIES T. 2001. Rapid fractionation of grape seeds proanthocyanidins. J Agricult Food Chem 49: 5732-5735.

SCHMitz W, CECCHINI R, ESTEVÃo D AND SARIDAKIS H. 2009. Hepatic protection effect of the alcoholic extract from Camellia sinensis (L.) Kuntze (green tea) in Wistar rats treated with diethylnitrosamine. Rev Bras Farmacog 19: 702-709.

SHAHIDI F AND NACZK M. 1995. Food phenolics: sources, chemistry, effects, applications, $2^{\text {nd }}$ ed., Lancaster: Technomic Publishing Company, $331 \mathrm{p}$.

Singleton V, ORTHOFER R AND LAMUELA-RAVENTOS R 1999. Analysis of total phenols and other oxidation substrates and antioxidants by means of Folin-Ciocalteau reagent. In: PACKER L (Ed), Methods in Enzymology, Oxidant and Antioxidant (Part A), Boston: Academic Press, Massachussetts, USA, p. 159-178.

SOUZAG, HAas A, Von Poser G, Schapoval EAND ElisabETSKY E. 2004. Ethnopharmacological studies of antimicrobial remedies in the south of Brazil. J Ethnopharmacol 90: 135-143. 
Spada P, Dani C, Bortolini G, Funchal C, Henriques J AND SAlvador M. 2009. Frozen Fruit Pulp of Euterpe oleraceae Mart. (Acai) Prevents Hydrogen PeroxideInduced Damage in the Cerebral Cortex, Cerebellum, and Hippocampus of Rats. J Med Food 12: 1084-1088.

SROKA Z AND CIROWSKI W. 2003. Hydrogen peroxide scavenging, antioxidant and anti-radical activity of some phenolic acids. Food Chem Toxicol 41: 753-758.

Tseng T, Wang C, KaO E And Chu H. 1996. Hibiscus protocatechuic acid protects against oxidative damage induced by tert-butylhydroperoxide in rat primary hepatocytes. Chem Biol Interact 101: 137-148.

Tibiriçá E, Almeida A, Caillleaux S, Pimenta D, Kaplan M, LeSSA M AND FigueIREDO M. 2007. Pharmacological mechanisms involved in the vasodilator effects of extracts from Echinodorus grandiflorus. J Ethnopharmacol 111: 50-55.
Van Breda SV, VAn Der Merwe CF, Robbertse H AND APOSTOLIDES Z. 2013. Immunohistochemical localization of caffeine in young Camellia sinensis (L.) O. Kuntze (tea) leaves. Planta 237: 849-858.

Veiga V, Pinto A And Maciel M. 2005. Medicinal plants: safe cure? Quim Nova 28: 519-528.

WeltMan M, FARRELl G, HALl P, INGELMAN-SUNDBERG M AND LIDDLE C. 1998. Hepatic cytochrome P450 2E1 is increased in patients with nonalcoholic steatohepatitis. Hepatology 27: 128-133.

WILLS E. 1996. Mechanism of lipid peroxide formation in animal tissues. Biochem J 99: 667-676.

YAMAGUChI T, TAKAMURA H, MATOBA T AND TERAO J. 1999. HPLC method for evaluation of the free radical scavenging activity of foods by using 1,1-diphenyl-2-picrylhydrazyl. Biosci Biotechnol Biochem 62: 1201-1204. 
